\title{
The Impact of Service Quality Delivery on Customer Satisfaction in the Banking Sector in Riyadh, Saudi Arabia
}

\author{
Ghalib Sanjuq ${ }^{1}$ \\ ${ }^{1}$ School of Economics \& Administrative Science, Al Imam ibn Muhammad ibn Saud Islamic University, Riyadh, \\ Saudi Arabia \\ Correspondence: Dr. Ghalib Sanjuq, Assistant Professor, School of Economics \& Administrative Science, Al Imam \\ ibn Muhammad ibn Saud Islamic University, Riyadh, Saudi Arabia. Tel: 966-56-839-9255. E-mail: \\ dr.ghalibsanjuq@hotmail.com
}

Received: June 7, 2014

doi:10.5430/ijba.v5n4p77

\author{
Accepted: June 28, $2014 \quad$ Online Published: July 4, 2014 \\ URL: http://dx.doi.org/10.5430/ijba.v5n4p77
}

\begin{abstract}
This study aimed to evaluate what impact service quality that underlies the SERVQUAL model has on customer satisfaction in Saudi Arabia's banking sector. The study was quantitative in nature and involved distributing a structured, pre-tested, self-administered questionnaire that was based on a convenience method to 412 customers of various bank in the Saudi capital city of Riyadh, during the fall of 2014. The response rate was 67 percent and the study data was analyzed using SPSS and a reliability coefficient (alpha) was determined. Regression analysis found a positive relationship among assurance, empathy, and responsiveness, but that this relationship has no significant effect $(\mathrm{P} \geq 0.50)$ on customer satisfaction. Reliability was found to have a negative relationship to customer satisfaction, but no significant effect on the same. Only tangibles were found to have a positive relationship and a significant impact $(\mathrm{P}<0.50)$ on customer satisfaction. The results show that, in the retail banking sector, the servqual model remains an effective way of measuring customer satisfaction. Because customer value is an asset to organizations, organizations must ensure that they provide the right products and services, supported by the right promotion, at the right time for their customers.
\end{abstract}

Keywords: servqual, customer satisfaction, local Saudi banks

\section{Introduction}

Banking is one of the Saudi economy's most important sectors and represented approximately one-third of the total market capitalization of all the country's listed companies in Saudi Arabia. Banks in Saudi Arabia have a long history, including large-scale development when oil prices soared in the 1970s. In 1966, SAMA introduced the Banking Control Law to regulate the banking sector. Before 1975, the Saudi government had been largely open to foreign-owned banks wishing to open branches, leading to 10 international banks having 23 branches in the country by late 1975 (Al-Dukheil, 1995). The environment for Saudi banks, both domestically and regionally, is becoming increasingly competitive as the number of banks operating in the country almost doubled to 20 by 2006.

The success or failure of a service provider depends largely on the quality of its relationship with its customers (Panda, 2003), which helps determine customer satisfaction (Lymperopoulos et al., 2006). Almost all organizations compete based on service, to some degree. The American Management Association's most exhaustive study involved a survey of more than 3000 respondents in several countries. Seventy-eight percent of these respondents reported that the key to competitive success was improving the quality and service they provided to customers, while 92 percent indicated that, regardless of their job description, one of their key responsibilities is to provide superior service (Greenberg, 1990).

\section{A. Customer Satisfaction}

It is important to understand what 'customer satisfaction' actually means. In business circles, the term refers to the kind of products and services a company provides in order to meet and exceed its customers' expectations. Organizations within the same market sector must assess the quality of their services if they are to attract and retain customers. It appears as though many researchers have conceptualized customer satisfaction as the feeling of pleasure or disappointment that an individual gains from comparing a perceived performance or outcome against 
their expectations (Oliver, 1981; Brandy and Robertson, 2001; Lovelock, Patterson and Walker, 2001). The two usual conceptualizations of satisfaction are transaction-specific satisfaction and cumulative satisfaction (Aldlaigan and Buttle, 2002; Yi and La, 2004). The former indicates how the customer evaluates his or her experience and the way that he or she reacts to a service encounter (Boshoff and Gray, 2004). Customer who experience a product or service for the first time express this reaction. Cumulative satisfaction, on the other hand, refers to how the customer evaluates his or her consuming experience overall (Johnson et al., 1995). Based on this overall evaluation, customers set a personal standard that they use subsequently to gauge service quality (SQ). However, there is general agreement that the measurement of customer satisfaction is a post-consumption assessment about the products or services gained (Churchill and Surprenant, 1982; Yuksel and Rimmington, 1988).

\section{B. Customer Satisfaction in Retail Banking}

Higher SQ means higher customer satisfaction. There is general agreement that the banking sector has no recognized and standardized scales with which to measure customers' perceptions of the quality of a bank's service. Consequently, gaining a competitive advantage by offering high-quality service is becoming increasingly important for survival in this sector. However, the unique characteristics of services - intangibility, inseparability, heterogeneity, and perishability - make it difficult for service providers to measure SQ (Bateson, 1985). Therefore, a number of measuring models have been developed with the aim of measuring service quality perceptions (Bahia and Nantel, 2000; Aldlaigan and Buttle, 2002).

\section{Service Quality}

Providing high-quality services can enhance customer retention rates, attract new customers through word-of-mouth, increase productivity, lead to higher market share, reduce operating costs and staff turnover, and improve financial performance, profitability, and morale among employees (Julian and Ramaseshan, 1994; Lewis and booms, 1983).

Although issues related to SQ have attracted increasing attention in management and academia, much of this focus has been on developed countries (Herbig and Genestre, 1996), despite the rapid growth of services in emerging countries (Malhotra et al., 1993). Service qualities may have been overlooked because of the sellers' market conditions that prevail in these emerging economies (Samli and Frohlich, 1992).

Several theoretical SQ models have been developed as award-based frameworks that promote quality awareness and encourage organizations to perform self-assessment in order to identify areas in which they can improve and to develop plans for further action.

The SERVQUAL instrument, developed by Parasuraman et al. (1990), relates to the customer's perceived measurement of service quality, where perceived service quality is defined as the degree and direction of the discrepancy between a customer's perceptions and their expectations (Parasuraman et al., 1990). The measurement methodology involves determining the customer's expectations of a particular service and then measuring the same customer's perceptions of the service he or she received on the same framework.

The SERVQUAL model is based on measures of the Performance-Expectation (P-E) gap across the following 10 dimensions: access, competence, communication, credibility, courtesy, responsiveness, reliability, tangibles, security, and understanding the customer. PZB consolidated these dimensions into the five following dimensions of service:

1 Tangibles How physical facilities, equipment, personnel, and communication materials appear

2 Reliability The extent to which the promised service can be performed accurately and reliably

3 Responsiveness Willingness to provide a prompt and helpful service to customers

4 Assurance Employees' knowledge, courtesy and ability to convey trust and confidence

5 Empathy A company's caring, individualized attention to its customers

The standard instrument developed to measure what is known as "gap 5" (that is, the difference between the perceived SQ and the SQ expected by the customer) is based on the five dimensions outlined above and is comprised 22 statements. The instrument starts by measuring the respondent's SQ expectation and then his or her perception of the actual SQ. The difference is used as gap 5.

A literature review by Albarq (2013) identified that few studies have applied the SERVQUAL model to customer loyalty in developing countries. If managers in the banking industry can understand the impact that the SQ underlying the SERVQUAL model has on customer loyalty, they may be able to focus their efforts on the areas that make the greatest contribution to customer retention. The insights offered by the present study will help understand the impact of various factors related to e-commerce customer satisfaction in the context of Saudi Arabia. In addition 
to the lack of data about SQ and customer satisfaction in the banking industries of developing countries, most of the SQ-measuring models were created in developed countries (Kotler et al., 1999). Albarq (2014) argued that the outcomes of these studies have also been influenced by culture and questioned the validity of applying findings from developed countries to less-developed ones.

This paper seeks to measure customers' satisfaction with banking services rendered in Riyadh, the capital of Saudi Arabia. The paper also briefly reviews some of the approaches to measuring customer satisfaction.

\section{Research Theoretical Model}

Figure 1 (adapted from Agus et al., 2007) shows the theoretical model that serves as a guide for the present study.

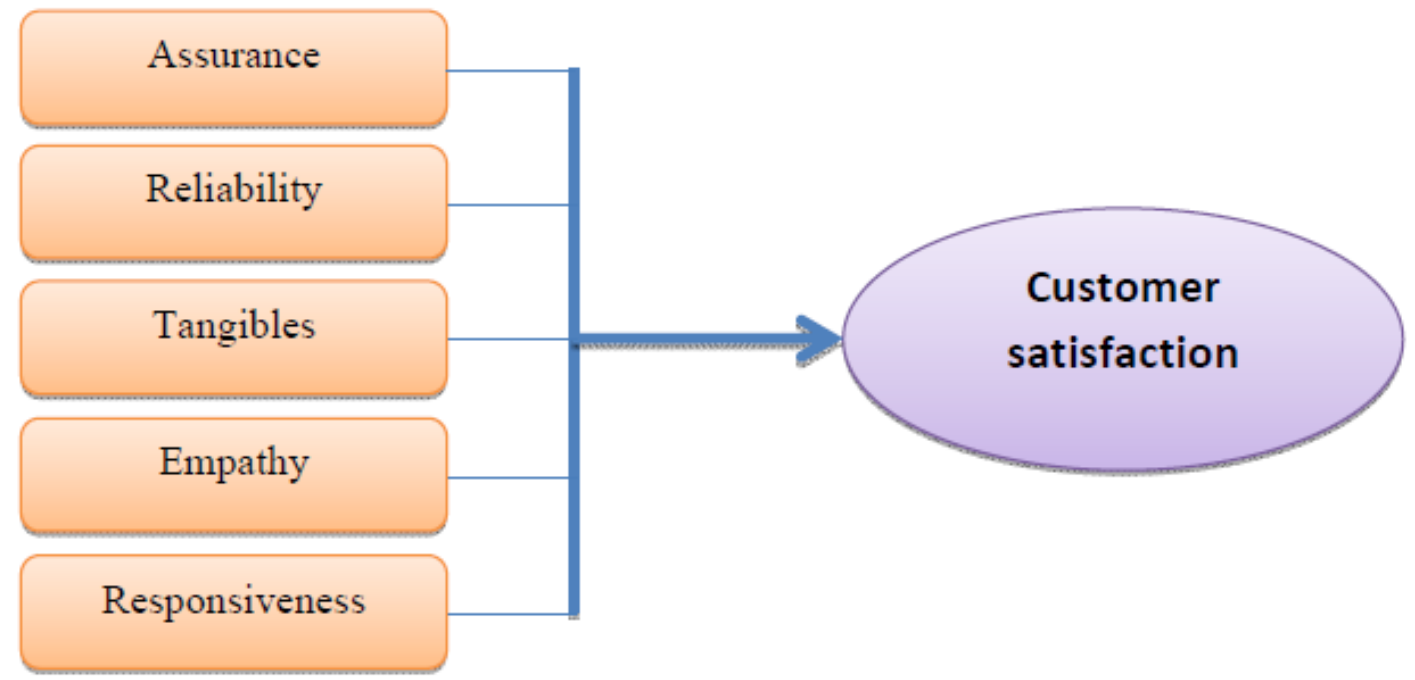

We propose the five following hypotheses:

H1: Assurance has a significant positive effect on customer satisfaction.

H2: Reliability has a significant positive effect on customer satisfaction.

H3: Tangibles has a significant positive effect on customer satisfaction.

H4: Empathy has a significant positive effect on customer satisfaction.

H5: Responsiveness has a significant positive effect on customer satisfaction.

\subsection{Method}

The empirical study was carried out in Riyadh, with bank customers the target population. The convenience method was used for sample selection. A total of 407 questionnaires were initially collected, but some were rejected because they had not been filled in correctly in, and the eventual sample was comprised of 319 valid respondents. Data was gathered during March and May 2014 and questionnaires were delivered in person to the respondents. Saudi Arabian banks are required to have separate sections for males and females, so female assistants distributed the questionnaires to female respondents. Participation was voluntary and was limited to customers who held at least one bank account. The questionnaire was translated from English into Arabic and checked to make sure that the language was equivalent in both versions.

The questionnaire has three distinct parts. The first part dealt with the respondents' demographic information and was designed with multiple choice. The second part of the questionnaire asked respondents to rate their level of satisfaction with their bank using a five-point scale, the options for which were "Strongly disagree", "disagree", "no comment", "agree" and "strongly agree". The final part sought to collect the respondents' opinions regarding the importance of SERVQUAL when choosing a retail bank. Responses varied from one respondent to another based on their experiences and opinions.

The fact that the proposed instrument had been carefully constructed, refined, and validated via an extensive literature review meant that it had adequate content validity. The researcher also sought assistance from seven specialists in this field to review the questionnaire and opine whether the questions were suitable. The final version 
of the questionnaire was influenced by the suggestions and comments of these specialists. In addition, I followed Nunnally's (1978) recommendation to carry out a pre-test on a similar group. This test involved asking 30 people whether they encountered any difficulties while completing the questionnaire. None of these respondents reported any problems. The data was analyzed using the SPSS software (version 18.0).

\section{Results}

Table 1. Personal profile of respondents $(n=319)$.

\begin{tabular}{llcc}
\hline Profile & Description & Number of Respondents & (\% of total) \\
\hline \multirow{4}{*}{ Age } & $18-29$ & 130 & 40.7 \\
& $30-39$ & 82 & 25.7 \\
\multirow{5}{*}{ Gender } & $40-49$ & 58 & 18.2 \\
& 50 and above & 49 & 15.4 \\
\multirow{5}{*}{ Education Level } & Male & 188 & 59.0 \\
& Female & 131 & 41.0 \\
& High school & 111 & 34.8 \\
& Bachelor's degree & 124 & 38.9 \\
Income per month & Master's degree & 52 & 16.3 \\
& Doctoral degree & 32 & 10.0 \\
& Less than 5000 SAR & 63 & 19.7 \\
& 5000-10,000 SAR & 105 & 32.9 \\
& 10001-15,000 SAR & 95 & 29.8 \\
\hline
\end{tabular}

Table 1 presents the results of using descriptive statistics to analyze the recorded demographic variables.

Initially, I used exploratory factor analysis (EFA) to identify the constructs dimension in order to choose the higher factor loadings, the results of which are shown in Table 2. The high KMO measure of the factor analyses meets the necessary statistical assumptions.

Table 2. Rotated component matrix

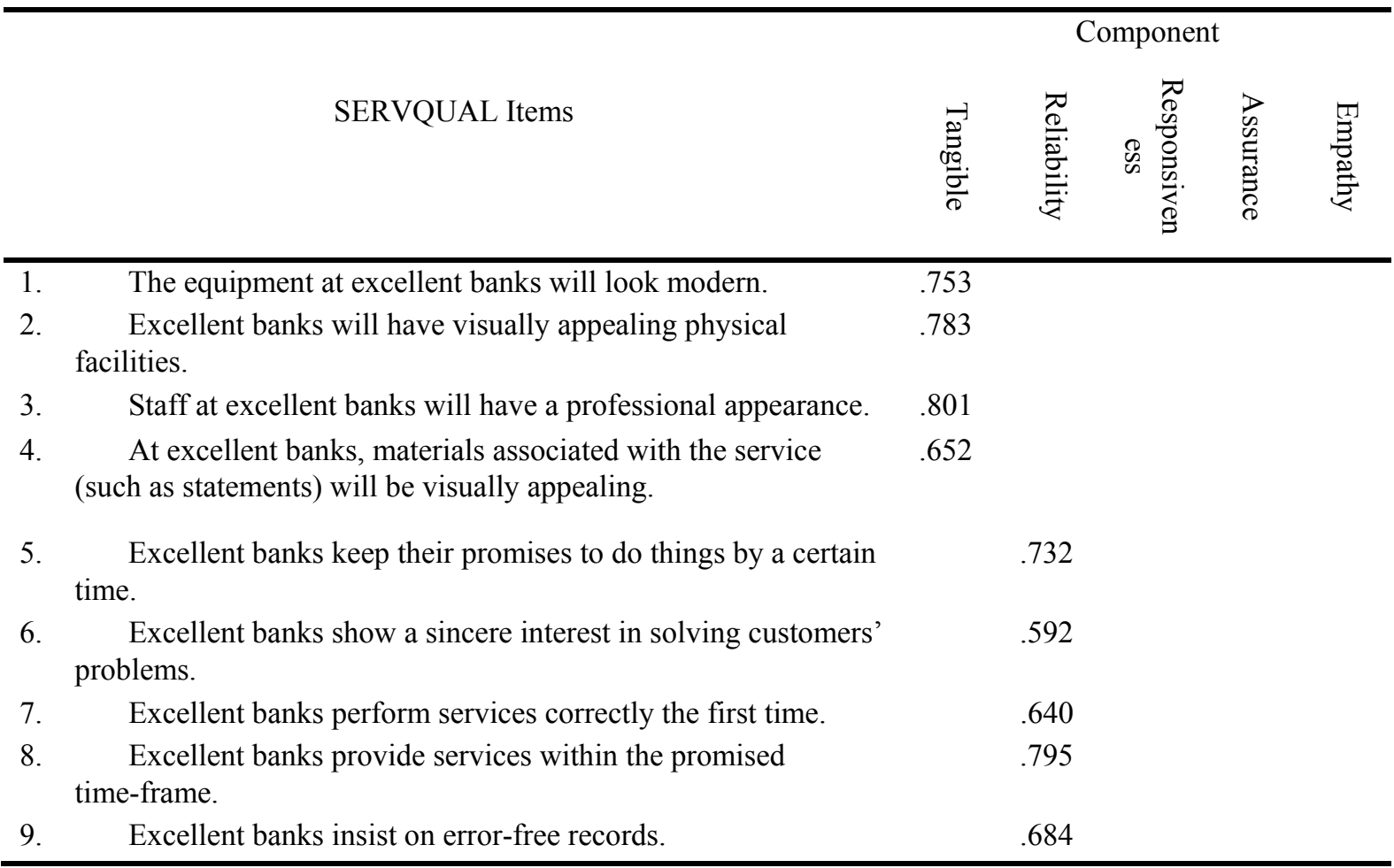


10. Staff at excellent banks tell customers exactly when certain

.613 services will be performed.

11. Staff of excellent banks will deliver prompt service.

12. Staff at excellent banks are always willing to help customers.

13. Staff excellent banks are never too busy to respond to customers' requests.

14. Staff at excellent banks will behave in a way that instils confidence in customers.

15. Customers of excellent banks feel safe conducting transactions.

16. Staff at excellent banks are consistently courteous to customers.

17. Staff at excellent banks have the knowledge required to answer customers' questions.

18. Excellent banks provide individual attention to customers. their customers.

20. Staff at excellent banks give customers personal attention.

We loaded all items onto the dimension for which they were designed. All of the factor loadings were higher than 0.5 , which meant that each item was loaded higher on its associated construct than on any other construct. As Hair et al. (2006) suggested, we considered a factor loading that is higher than 0.35 to be statistically significant at an alpha level of 0.05 . This finding provides support for the measurement's discriminate validity.

A reliability test examines how consistent individuals are in their responses. Cronbach's alpha measures the survey's internal consistency and research variables are based on sample estimation.

Table 3. SERVQUAL scale reliability analysis

\begin{tabular}{lcc}
\hline & Construct & Reliability Test \\
& No. of Items & $\alpha$ \\
\hline Tangible & 4 & 0.967 \\
Reliability & 5 & 0.815 \\
Responsiveness & 4 & 0.949 \\
Assurance & 4 & 0.940 \\
Empathy & 5 & 0.923 \\
\hline
\end{tabular}

For the five above-mentioned SERVQUAL dimensions, the Cronbach's alpha reliability coefficients are similar to those of previous studies. Although 0.7 has been suggested as an accepted cutoff point (Hair et al., 1995), any value greater than 0.6 is considered satisfactory (Hair, et al., 2006; Albarq et al., 2013). The reliability analysis measures its stability in various conditions. 
Table 4 indicates that, together, assurance, reliability, tangibles, empathy, and responsiveness had a 70.1 percent effect on customer satisfaction. The $\mathrm{R}^{2}$ for the five dimensions indicates that these variables have a strong effect on customer satisfaction. The changes in the F value (35.874) are significant, implying that the model is robust and fit.

Table 4. Model summary

\begin{tabular}{cccccccc}
\hline Model & $\mathrm{R}$ & \multirow{2}{*}{$\mathrm{R}^{2}$} & Adjusted $\mathrm{R}^{2}$ & Std. Err & \multicolumn{3}{c}{ Change St. } \\
\hline 1 & $0.792 \mathrm{a}$ & 0.701 & 0.687 & 3.81462 & 35.874 & 5 & 0.000 \\
\hline
\end{tabular}

a. Predictors: (Constant), responsiveness 1, reliability 1, tangible1, assurance1, empathy 1

b. Dependent Variable: customer satisfaction 1

c. $\mathrm{P}<0.01$

Table 5. Results of regressions

\begin{tabular}{|c|c|c|c|c|c|}
\hline \multirow[t]{3}{*}{ Model } & \multirow{2}{*}{\multicolumn{2}{|c|}{ Understandardized Coefficients }} & \multirow{3}{*}{$\begin{array}{c}\text { Standardized } \\
\text { Coefficients } \\
\beta \\
\end{array}$} & \multirow{3}{*}{$\mathrm{t}$} & \multirow{3}{*}{ Sig. } \\
\hline & & & & & \\
\hline & B & Std. Error & & & \\
\hline 1 (Constant) & 14.983 & 2.361 & & 7.411 & 0.000 \\
\hline Tangible & 0.798 & 0.156 & 0.618 & 4.138 & \\
\hline Reliability & -0.198 & 0.169 & -0.134 & -1.194 & 0.233 \\
\hline Responsiveness & 0.188 & 0.227 & 0.117 & 0.799 & 0.421 \\
\hline Assurance & 0.119 & 0.211 & 0.077 & 0.601 & 0.538 \\
\hline Empathy & 0.138 & 0.218 & 0.089 & 0.698 & 0.491 \\
\hline
\end{tabular}

a. Dependent Variable: customer_satisfaction_1

b. $\mathrm{P}<0.01$

As Table 5 shows, only tangibles had a significant effect on customer satisfaction (p-value $<0.01$ ).

\section{Discussion}

\subsection{Assurance}

Assurance, which is the customer's feeling of safety, has a positive relationship with customer satisfaction, but no significant effect on it. Based on the responses, customers do not consider assurance to be an important part of the service quality. Many customers have reported security breaches, either in internet banking or phone banking, and this is usually due to customers' carelessness. Banks should increase the level of assurance in their servicesin order to retain existing customers and even attract new ones.

\subsection{Reliability}

Reliability concerns the accuracy and timeliness of the service. According to the responses to our questionnaire, reliability has no significant impact on customer satisfaction, perhaps due to the increased popularity of phone and internet banking, which gives customers an alternative to face-to-face customer service. The 24/7 nature of internet and phone banking means that retail banks can reduce their operational costs by not having to extend branch hours and employ extra staff. Customers now place higher demands on the reliability of machines than on humans when dealing with banks.

\subsection{Tangibles}

Tangibles includes the company's facilities, equipment and representatives. The present study has identified a positive correlation and high level of significance between tangibles and customer service. When retail banks reduced their operating hours to five days per week, customers found it difficult to visit the branches in person, and have instead used telephone and internet banking. 


\subsection{Empathy}

Our results suggest that no significant positive relationship exists between empathy and customer satisfaction. Although most customers would enjoy using new bank facilities, a number of customers prefer face-to-face service.

\subsection{Responsiveness}

Responsiveness is how timely a bank reacts to its customers' needs. In our study, responsiveness has a relationship with customer satisfaction, but no significant effect on it; this enables us to conclude that responsiveness is a positive feature of quality service, but not a must. Again, this result indicates that customers prefer to deal with machines rather than humans. Machines generally have shorter response times and can be improved upon constantly, whereas human responsiveness can be affected by emotion, reducing productivity.

\section{Limitations}

This study has certain limitations. Firstly, we did not consider control the variables of socio-demographic variables. Secondly, the questionnaires were only administered to respondents in Riyadh; future studies could be extended to a wider population.

\section{Conclusion}

All of the components in a service quality program - assurance, empathy, reliability, tangibles, and customer satisfaction - should be followed and implemented effectively. Managers should not focus on the bank's profit-related objectives, but must also look at the needs of the bank's customers. Managers should implement customer relations training for all frontline staff. This study has shown that the SERVQUAL model is still the most effective model with which to measure customer satisfaction in retail banking. In order to retain customers, organizations must ensure that they provide their customers with the right products and services at the right time. The measurement of service quality can provide specific data that can be used in quality management; hence, service organizations would be able to monitor and maintain quality service. Assessing service quality and better understanding how various dimensions affect overall service quality would enable organizations to efficiently design the service delivery process. By identifying strengths and weaknesses pertaining to the dimensions of service quality organizations can better allocate resources to provide better service and ultimately better service to external customers. Generally speaking, the study of service quality is both important and challenging. Future efforts should continue to advance the understanding of the concept and the means to measure and improve service quality.

\section{References}

Agus, A., Barker, S., \& Kandampully, J. (2007). An exploratory study of service quality in the Malaysian public service sector. International Journal of Quality \& Reliability Management, 24(2), 177-190. http://dx.doi.org/10.1108/02656710710722284

Albarq, A. N. (2013). Applying a SERVQUAL Model to Measure the Impact of Service Quality on Customer Loyalty among Local Saudi Banks in Riyadh. American Journal of Industrial and Business Management, 3, 700. http://dx.doi.org/10.4236/ajibm.2013.38079

Albarq, A. N. (2014). Industrial Purchase among Saudi Managers: Does Country of Origin Matter?. International Journal of Marketing Studies, 6(1), p116. http://dx.doi.org/10.5539/ijms.v6n1p116

Albarq, A., Suleiman, A., \& Almualla, A. (2013). Using structural equation modeling for beginner. Jordan, Amman: Ithraa, Inc.

Aldlaigan, A. H., \& Buttle, F. A. (2002). SYSTRA-SQ: a new measure of bank service quality. International Journal of Service Industry Management, 13(4), 362-381. http://dx.doi.org/10.1108/09564230210445041

Bateson, John E. (1985). Self-service consumer: An exploratory study. Journal of retailing.

Boshoff, C., \& Gray, B. (2004). The relationships between service quality, customer satisfaction and buying intentions in the private hospital industry. S Afr J Bus Manag, 35(4), 27-35.

Brown, T. J., Churchill Jr, G. A., \& Peter, J. P. (1993). Improving the measurement of service quality. Journal of retailing, 69(1), 127-139. http://dx.doi.org/10.1016/S0022-4359(05)80006-5

Churchill Jr, G. A., \& Surprenant, C. (1982). An investigation into the determinants of customer satisfaction. Journal of Marketing Research (JMR), 19(4).

Dukheil, Abdulaziz M. (1995). The banking system and its performance in Saudi Arabia. Al Saqi. 
Greenberg, Jerald. (1990). Organizational justice: Yesterday, today, and tomorrow. Journal of management, 16(2), 399-432. http://dx.doi.org/10.1177/014920639001600208

Herbig, P., \& Genestre, A. (1996). An examination of the cross-cultural differences in service quality: the example of Mexico and the USA. Journal of Consumer Marketing, 13(3), 43-53. http://dx.doi.org/10.1108/07363769610118949

Iymperopoulous, C., Chaniotakis, I. E., \& Soureli, M. (2006). The importance of service quality in bank selection for mortgage loans. Managing Service Quality, 16(4), 365-379. http://dx.doi.org/10.1108/09604520610675702

Johnson, M. D., \& Fornell, C. (1995). A Framework for comparing customer satisfaction across individuals and product categories. Journal of Economic Psychology, 12(2), 267-286. http://dx.doi.org/10.1016/0167-4870(91)90016-M

Julian, C. C., \& Ramaseshan, B. (1994). The role of customer-contact personnel in the marketing of a retail bank's services. International Journal of Retail \& Distribution Management, 22(5), 29-34. http://dx.doi.org/10.1108/09590559410067316

K. Bahia, \& J. Nantel. (2000). A reliable and valid measurement scale for perceived service quality of banks. International Journal of Bank Marketing. 18(2), 84-91. http://dx.doi.org/10.1108/02652320010322994

Lewis, R. C., \& Booms, B. H. (1983). The marketing aspects of service quality. Emerging perspectives on services marketing, 65(4), 99-107.

Lovelock, C., \& Wirtz, J. (2001). Service Marketing People, Technology, Strategy, United States of America, Hamilton Printing Co, pp.106-107. Aldlaigan and Buttle, 2002. Retrieved from http://trove.nla.gov.au/version/34376546

Malhotra, N.K., Agarwal, J., \& Peterson, M. (1993). Cross-cultural marketing research: methodological issues and guidelines. International Marketing Review, 13(5), 7-43.

Oliver, R. (1981). A cognitive model of the antecedent and consequences of satisfaction decisions. Journal of Marketing, 17(10), 460-9.

P. Kotler, S. Ang, S. Leong, \& C. Tan. (1999). Marketing Management: An Asian Perspective. Prentice Hall Inc., Upper Saddle River.

Panda, T. K. (2002). Creating customer lifetime value through effective crm in financial in services industry. Journal of Services Research, 2(2).

Rimmington, Mike, \& Atila Yüksel. (1998). Tourist satisfaction and food service experience: Results and implications of an empirical investigation. Anatolia, $9(1), \quad 37-57$. http://dx.doi.org/10.1080/13032917.1998.9686958

Samli, A. C., \& Frohlich, C. J. (1992). Consumer friendly financial services: Combining efficiency and effectiveness. Journal of Business and Psychology, 8(2), 145-162. http://dx.doi.org/10.1007/BF02230382

Saudi Arabian Monetary Agency, “Annual SAMA Re- port," 2013. Retrieved from http://www.sama-ksa.org/sites/samaen/pages/home.aspx

Yi, Y., \& La, S. (2004). What influences the relationship between customer satisfaction and repurchase intention? Investigating the effects of adjusted expectations and customer loyalty. Psychology \& Marketing, 21(5), 351-373. http://dx.doi.org/0.1002/mar.20009 